\title{
A GUERRA COMO MODO DE GOVERNO EM FAVELAS DO RIO DE JANEIRO
}

\section{Alexandre Magalhães (iD}

Professor do Departamento de Sociologia e do Programa de Pós-Graduaçáo em Sociologia, Universidade Federal do Rio Grande do Sul (UFRGS), Porto Alegre - RS, Brasil. E-mail: alexandre.magalhaes@ufrgs.br

DOI: $10.1590 / 3610600 / 2021$

\section{Introdução}

Há alguns anos pesquisadores, ativistas de direitos humanos e moradores de favelas vêm afirmando que a gestấo e a regulação da vida coletiva, especialmente em alguns territórios, são articuladas a partir de uma lógica militarizada. Ou seja, a militarização tem atravessado e configurado o cotidiano de vida de milhares de pessoas, e caracterizado, cada vez mais, as formas de governo no Rio de Janeiro. Nessa configuração, torna-se evidente o embotamento entre a gestão urbana e a gestão da ordem, que são articuladas, como afirma Telles (2015), a partir de princípios securitários. ${ }^{1}$ A combinação das duas formas de gestão ressoa aquilo que Graham (2016) denomina "urbanismo militar", isto é, as formas de governo urbano são cada vez mais - e de forma

Artigo recebido em: 30/01/2020

Aprovado em: 28/06/2020 contínua - realizadas a partir de uma racionalidade militar. A cidade, nesse contexto, é tratada como um campo de guerra. Além do mais, tal racionalidade se efetiva tanto pela territorialização dos mecanismos de controle e seus modos de operar (Telles, 2015) quanto pela encarnação em determinados corpos, que se tornam os alvos preferenciais - a alteridade radical - dos dispositivos de captura (Gonzalo, 2016) destes mecanismos.

O Rio de Janeiro é um caso interessante para observar a constituição de tal configuração justamente em função das inúmeras iniciativas governamentais voltadas para governar e gerir a cidade e algumas de suas populaçôes. No campo chamado da "segurança pública”, diferentes experimentaçôes biopolíticas, como venho denominando tais experiências de governo, foram sendo elaboradas e efetivamente testadas nos últimos anos, como foi o caso das Unidades de Polícia Pacificadora (UPPs) e, mais recentemente, a intervenção federal comandada pelo Exército. Tais experimentaçóes 
biopolíticas pressupõem justamente a mobilização de variados e diversificados mecanismos de controle que buscam atualizar formas de governo populacional. Estes mecanismos de governo de populaçóes pobres urbanas, associados ao campo da "segurança pública", somam-se e articulam-se a outros que proliferaram nos últimos tempos no Brasil - atualizando, de alguma maneira, as tecnologias de gestão que historicamente lhes foram direcionadas -, tais como os processos de remoção de favelas que eu mesmo investiguei, no contexto do Rio de Janeiro (Magalhães, 2019), assim como outros pesquisadores (Guterres, 2014; Azevedo e Faulhaber, 2015); assassinatos e chacinas provocadas por policiais (Farias, 2014); o desaparecimento forçado em período democrático (Araújo, 2014); as prisóes e outras instituições de controle (Mallart, 2019; Godoi, 2017); pessoas em situação de rua (Rui, Martinez e Feltran, 2016; Lemóes, 2017); pessoas usuárias de drogas em situação de rua (Rui, 2014). Muitas dessas experiências no Rio de Janeiro também podem ser encontradas em Birman et al. (2015).

É importante destacar, ainda, como muitas dessas experimentações se efetivaram em circunstâncias específicas que ofereceram as condiçôes de possibilidade para a sua realização, como a preparação da cidade para os Jogos Olímpicos ou, mais recentemente, num quadro de "crise" política e econômica do estado. ${ }^{2}$

Nessa angulação, é possível destacar o crescimento vertiginoso observado nos últimos tempos dos homicídios provocados pelas forças de segurança. Pelos números recentes disponíveis relacionados ao ano de 2019 - disponibilizados pelo Instituto de Segurança Pública (ISP) -, as polícias do Rio mataram 1810 pessoas, o que demonstra um considerável crescimento em relaçáo a 2018 (quando 1534 pessoas foram assassinadas pelas forças de segurança). Foi o maior número em vinte anos, numa média de cinco pessoas assassinadas por dia. ${ }^{3}$ Esse incremento no ano de 2019 em relação ao anterior tem a ver com a escolha deliberada do governador eleito, Wilson Witzel, pela política do confronto e do extermínio.

Abertamente defendida por ele durante a campanha eleitoral, tal política passou a se tornar a pedra angular do seu governo. Logo depois de eleito, Witzel (2018) fez uma declaração que ganhou ampla repercussão: ao prometer utilizar "snipers" - atiradores de elite - como forma de "conter os bandidos", ele afirmou: "A polícia vai fazer o correto: vai mirar na cabecinha e... fogo". O "abate”, como ficou conhecida sua promessa para a política de segurança, seria de fato realizado, como podemos verificar nos números de mortes provocadas pela polícia, especialmente as chacinas (como a que ocorreu no Fallet-Fogueteiro, quando treze pessoas foram assassinadas pela polícia durante uma incursão).

Embora venha ocorrendo o crescimento das mortes provocadas pela polícia e de outros mecanismos de controle violento nos últimos anos, a inflexão decisiva nesse cenário político no qual a morte se torna o horizonte de governo (uma necropolítica, nos termos de Mbembe, 2016) foi justamente a intervenção federal nas forças de segurança ocorrida em fevereiro de 2018. Ali, me parece - e essa é a aposta central deste artigo -, tornou-se possível a consolidação da militarização como forma fundamental de realização da necrogovernança (Vianna, 2018), bem como a normalização da guerra como o seu paradigma político. ${ }^{4}$ Em outras palavras, estou afirmando que o incremento quantitativo (de mortes, equipamentos, tecnologias, "recursos humanos" militares, recursos econômicos vultosos) permitiu uma mudança qualitativa nas formas combinadas de gestão urbana e da ordem, no caso do Rio de Janeiro. E isso só foi possível, entre outros fatores, em função das inúmeras experimentaçóes biopoliticas, tanto aquelas que foram realizadas em favelas e periferias cariocas e brasileiras, como também na Palestina, Colômbia e, sobretudo, no Haiti. Tal configuração também repercute, atualiza e aprofunda formas de controle violento e da produção da guerra contra populaçóes ao longo de nossa história, como aquelas que foram dirigidas, desde o período colonial, às populaçóes indígenas, como apontam Souza Lima (1995) e Oliveira (2014).

Todas estas experimentaçóes biopoliticas ao longo do tempo, de alguma forma, prepararam o terreno político e social no qual a guerra se transforma seguindo Mbembe, se atualiza - no modo mesmo de governo populacional, a medida a partir da qual se traça a linha entre o excluído e o incluído, o dentro e o fora, aqueles e aquelas que pertencem a uma "humanidade comum" e os que deixam de participar 
dela, postos no âmbito da natureza, localizados à meia distância de uma cidadania tornada impossível de se realizar e alcançar. ${ }^{5}$

Nesse sentido, parece ocorrer um deslizamento da maneira como Leite (2000) interpretava as figuraçôes da violência, no caso do Rio de Janeiro, a partir da noção da "metáfora da guerra". Ou seja, não se trataria mais ou apenas de um conjunto de representaçóes que interpelariam determinadas práticas tidas como violentas (em geral associadas às favelas e seus moradores), mas de um modo mesmo de gerir e governar. Nesse sentido, Leite e Birman (2018) e Rui e Feltran (2017) se perguntam se ainda é possível falar da guerra como uma metáfora. No caso das autoras, elas afirmam, de maneira muito próxima ao argumento deste artigo:

que a guerra, no caso do Rio de Janeiro, é um eixo de intervenção fundamental na vida da cidade justamente porque a produçáo de mortes no cotidiano se transformou, há muito tempo, em uma maneira de gerir a cidade. (Leite e Birman, 2018, p. 32)

De modo também muito próximo, Rui e Feltran (2015, p.1) apontam:

"A guerra é mesmo uma metáfora? 'Guerra às drogas', 'guerra ao crime', 'guerra ao crack', acompanhadas de ocupação militar de territórios, tornaram-se campanhas e açôes centrais para os governos".

Como é possível observar a partir do levantamento feito pelo Observatório da Intervenção, de fevereiro a dezembro de 2018 ocorreu um aumento de $33,6 \%$ no número de pessoas mortas pelas polícias no contexto da intervenção - foram 1375, em números absolutos - em relaçáo a 2017.6 Do conjunto das mortes violentas que ocorreram no Rio de Janeiro durante a intervenção, nada menos que $22,7 \%$ foram cometidas por policiais e militares. Além disso, de acordo com o Monitor da Violência, o Rio se transformou no estado com a maior taxa de mortes provocadas por policiais: 8,9 a cada 100 mil. $^{7}$
Diante desse cenário, e partindo da formulação de Mbembe (2016) quanto à centralidade das experiências coloniais (e também da escravidáo) para pensar a inscrição não só da vida, mas principalmente da morte no cerne das formas atuais de governar, Vianna e Magalhães (2019) afirmam que se torna impossível ignorar a força colonial que caracteriza as maneiras de gerir espaços, vidas, mortes e um conjunto variado de relaçôes no Rio de Janeiro e em outros lugares do Brasil. Nessa angulação, continuam os autores (2019, p.145): "Periferias e favelas no Rio são expressamente percebidas, administradas e imaginadas como territórios 'outros', zonas fronteiriças ou de margem [Das e Poole, 2004, 19] que podem e devem ser objeto de açôes singulares". A partir desse aporte, podemos avançar e afirmar que, ao nos depararmos com a guerra como o fundamento da ordem social e política contemporânea (um fundamento nada oculto, à diferença da afirmação de Agamben (2007)] sobre a biopolítica), estamos lidando com a produção de um modelo colonial de organização e gestáo da vida urbana.

Tal configuraçáo nos coloca o desafio intelectual e político - e esse artigo buscará oferecer algumas questóes nesse sentido - de refletir acerca das condiçóes de possibilidade da vida nos espaços urbanos contemporâneos atravessados por esse modelo colonial de gestáo da vida, agenciador da guerra. Chamar a atenção, por um lado, para as intensas e intensivas dinâmicas de "desfazimento da vida" (Das, 2007), isto é, conjuntos de práticas e açóes que fazem desorganizar, desestruturar e, no limite, eliminar certos modos de viver, determinadas formas de vida na cidade. E, por outro, para as inúmeras e multifacetadas maneiras de enfrentar e/ou contornar esses processos desarticuladores.

Nesse sentido, ao apostar na afirmação de que há uma mudança qualitativa nos modos de governar as populações urbanas caracterizada pelo acionamento constante da guerra e da produçáo da morte, buscarei descrever os delineamentos que tornam possível o funcionamento desta maquinaria de destruição de formas de vida e, de maneira muito preliminar - demandando desenvolvimentos posteriores -, apresentar uma experiência de resistência, tendo em vista o cenário urbano atual. 
Isso coloca uma pergunta cuja resposta apenas será esboçada nesse texto: quais resistências se inventam em ambientes de forte assimetria de poder e de violência institucional?

\section{A crise como modo de governo e a intervenção federal}

Desde que as Unidades de Polícia Pacificadora ${ }^{8}$ começaram a mostrar sinais de que não mais se efetivariam como dispositivo de controle de certas populaçôes (no caso, os moradores de favelas) e de gestão da ordem, o Rio de Janeiro passou a observar, cada vez mais, o crescimento vertiginoso dos chamados "confrontos" nas favelas, com aumento dos tiroteios, dos homicídios provocados por policiais, das mortes violentas em geral e de outros índices de violência. ${ }^{9}$ Acompanhando o cenário desolador do estado, a segurança pública também entraria em "crise".

Parte do aumento desses "confrontos" pode ser associada a uma reconfiguração - que precisa ser melhor estudada - do mundo do crime após a derrocada das UPPs. ${ }^{10}$ Isto é, um dos efeitos dessa experimentação biopolítica foi reorganizar as disputas em torno do tráfico de drogas e sua territorialização, fazendo aumentar os tais "confrontos". Em julho de 2017, diante de um cenário que se configurava como de uma crescente ingovernabilidade na área de segurança pública, o então governador do estado Luiz Fernando Pezão (hoje preso) - solicitou ajuda do governo federal.

O presidente à época, Michel Temer, elaborou um decreto autorizando o uso das Forças Armadas através da Garantia da Lei e Ordem (GLO), ${ }^{11}$ dispositivo constitucional controverso que permite a atuação de militares em situaçóes de "crise" como a que se verificava no Rio de Janeiro naquele momento (Martín, 2017). O decreto previa a destinação ao estado de 8.500 militares, além de 620 agentes da Força Nacional, que atuariam basicamente no apoio às açóes das forças de segurança local. ${ }^{12}$

A atuação do governo federal na segurança pública do Rio de Janeiro nesta ocasião e, posteriormente, com a intervenção, embora não fosse exatamente uma novidade, e mesmo permitida constitucionalmente, pareceu atualizar o modo muitas vezes desarticulado, fragmentado e conflituoso com que se estabelecem as relaçoóes e a distribuição de funçóes entre os entes federativos no que se refere ao chamado "combate à violência”, reforçando uma configuração institucional de:

ausência de regras que regulamentem as funçóes e o relacionamento das polícias federais e estaduais, e mesmo das polícias civis e militares que produz no Brasil um quadro de diversos ordenamentos para a solução de problemas similares de segurança e violência (Peres e Bueno, 2013, p. 126) ${ }^{13}$

Uma das consequências do rearranjo mencionado acima ocorreu em 17 de setembro do mesmo ano, na Rocinha. Uma disputa entre dois grupos rivais de traficantes, resultado de um racha na facção à qual ambos pertenciam, produziu quatro mortes e intensos tiroteios por vários dias. Ainda que tivessem informaçóes sobre a possibilidade de concretização do confronto entre os grupos criminosos, as forças de segurança apenas intervieram dias depois, a partir de uma ação espetacular de cerco das Forças Armadas, à qual se seguiria uma ocupaçáo por uma semana. ${ }^{14}$

Nessa configuração, é importante destacar o uso recorrente da GLO nos últimos anos no Brasil, especialmente na atuaçáo no campo da segurança pública. Entre janeiro de 2010 e dezembro de 2018, o governo federal gastou $\mathrm{R} \$ 2,6$ bilhóes em 49 operaçóes do tipo GLO realizadas pelas Forças Armadas, e desde 1992 foram efetivadas 136 operaçóes de Garantia de Lei e Ordem. ${ }^{15}$ Do ponto de vista formal, segundo a regulamentação que permite o recurso à GLO, as Forças Armadas deveriam agir de maneira apenas episódica, considerando o recorte de uma área restrita e por tempo limitado, "com o objetivo de preservar a ordem pública, a integridade da população e garantir o funcionamento regular das instituiçóes" (BRASIL, 2020). O acionamento da GLO se justificaria diante da incapacidade das forças de segurança locais de administrar os conflitos violentos existentes, um "estado de crise" que caracterizaria um determinado ordenamento social.

Segundo o dicionário Michaelis, crise significa "momento crítico" ou "conjuntura perigosa". Sociologicamente, podemos compreender "crises" 
como situações de desarranjo, indefinição e, no limite, indeterminação, nas quais as referências foram embaralhadas ou deixaram de operar. Não há dúvida de que as situações até aqui relatadas se definiriam, em parte, desta forma. A palavra "crise", quando mobilizada, parece algo transcendental, como se não dissesse respeito às açóes muito concretas empreendidas por sujeitos, também muito concretos, em situaçóes concretas. É como se girasse num vazio de sentido; "É a crise" e ponto. Mais do que isso: eximiria de responsabilidade aqueles que são seus maiores responsáveis, abrindo o terreno para que açôes truculentas e de legalidade duvidosa possam ser realizadas.

Contudo, é importante afirmar que a chamada "crise" resulta de uma opção deliberada de condução da vida coletiva. A "crise na segurança pública” - ou em qualquer outra área - é a expressão de decisóes políticas tomadas por determinadas pessoas e grupos; resulta de açóes cujos responsáveis são objetivamente identificáveis. Como afirma Safatle (2016), a fabricação contínua da "crise" se transformou num dos modos mais eficazes de governar. É o acionamento de situações de "crise" que justificam medidas de exceção cada vez mais rotineiras no governo da cidade. Nesse sentido, buscarei discutir adiante a configuração na qual emerge a intervenção federal nas forças de segurança pública do Rio de Janeiro em 2018, e suas consequências mais imediatamente visíveis na vida dos moradores de favelas.

\section{A intervenção federal no Rio de Janeiro}

Por meio do Decreto ${ }^{\circ} 9.288$, de 16 de fevereiro de 2018, o então presidente Michel Temer dava início à intervenção federal na segurança pública do estado do Rio de Janeiro. A justificativa para uma medida de tamanha envergadura política e social foi apresentada de forma resumida no parágrafo segundo do primeiro artigo: "O objetivo da intervenção é pôr termo a grave comprometimento da ordem pública no Estado do Rio de Janeiro". Naquela ocasião, foram repercutidas e exploradas incessantemente cenas de violência no estado, sobretudo de assaltos em áreas nobres, e também do número crescente de roubo de cargas.
Ao assinar o decreto, Temer usou expressóes como "medida extrema" e "derrotar o crime" para sustentar tal iniciativa governamental. A mobilização de expressões como essas não é novidade na história recente do Rio de Janeiro e do Brasil; é por meio delas que, há quarenta anos, as autoridades públicas buscam, de maneira espetaculosa, oferecer uma "solução definitiva" para a "onda de criminalidade" e para a "desordem". Como alguns críticos chegariam a afirmar na ocasião, essa "medida extrema" teria dois objetivos articulados no horizonte: primeiro, permitir uma sobrevida a um governo com baixíssimos índices de aprovação e marcado por duas denúncias de corrupção; segundo, estávamos em um ano eleitoral e uma ação numa área como a segurança pública historicamente costuma mobilizar a população. Ao menos do ponto de vista da aprovação popular da intervenção (segundo o Observatório da Intervenção, ao final da operação, ela era aprovada por cerca de $70 \%$ da população, mesmo sem que os resultados prometidos tivessem sido alcançados), o governo então poderia ter motivos para defender a ação como adequada, necessária e urgente. ${ }^{16}$

Outras críticas giravam em torno tanto da inconstitucionalidade do decreto (como aquela presente na Ação Direta de Inconstitucionalidade ADI 5.915/DF apresentada pelo Partido Socialismo e Liberdade) quanto da suposta "urgência" da medida. Em relação a essa última crítica, argumentava-se que, naquele momento, havia estados em situaçóes definidas como "muito piores" do que a do Rio de Janeiro e que não sofreram intervenção do governo federal. Além disso, o entendimento da medida como "eleitoreira" e "oportunista" seria reforçado pela divulgação do Plano Estratégico, por parte do Gabinete de Intervenção Federal (GIF) (BRASIL, 2018), apenas no final de maio daquele ano, plano este que se definia por "estabelecer as bases do planejamento estratégico e de gestão das atividades a serem desenvolvidas no âmbito do Gabinete de Intervenção Federal na Segurança Pública do Estado do Rio de Janeiro - GIF/RJ".

De acordo com Adey, Anderson e Graham (2015), em determinadas circunstâncias, uma dada "situação de crise" ou mesmo de "emergência" se transforma em algo relevante politicamente, pois seria numa configuração como essa que se justificariam 
ações e políticas "desproporcionais". A invocação da "emergência” (ou "urgência/crise”) em circunstâncias de aprofundamento de determinados conflitos pode se tornar um "aparelho de produção de desastres", a partir do qual vidas são passíveis de serem destruídas. ${ }^{17}$

É justamente nessa configuração atravessada pela invocação da emergência que toda e qualquer ação se tornaria "necessária", e "danos colaterais" seriam tratados como "inevitáveis". O então ministro da Justiça, Torquato Neto, definiu a situação acionando uma expressão que tem marcado uma mudança paradigmática nos conflitos relacionados à segurança pública atualmente: "guerra assimétrica”. Questionado se poderiamos definir de fato tal circunstância como uma guerra, e se a letalidade por parte das forças de segurança seria "inevitável”, o ministro ressaltou: "Em algum momento, lamentavelmente, vai [ocorrer mortes]. Não há guerra que não seja letal”. (Jardim, 2018). Tal entendimento seria reforçado pelo então presidente da República: "Se houver necessidade [o militar], parte para o confronto". Numa "guerra assimétrica”, tal como afirmado pelo ministro, tudo se torna possível, e a "única" modalidade de atuação é a do confronto, tendo como um horizonte sempre possível a morte. Como afirmou o comandante do Exército: "Esse risco sempre existe". É a normalização da morte de certas pessoas por meio da produção contínua de uma guerra "inevitável” para "combater a criminalidade". ${ }^{18}$

\section{Não é uma guerra?}

Interessante observar como se produziu um jogo discursivo que delineou uma zona cinzenta entre o que se afirmava publicamente em algumas ocasióes ("não se trata de uma guerra") e o que se efetivava (o uso de tanques de guerra e a afirmação da inevitabilidade do confronto, da morte e de danos colaterais). Por um lado, diante do "estado de crise" e da "urgência" do momento, apontava-se a necessidade de uma atuação contundente contra os "bandidos". Nesse sentido, todos os recursos disponíveis deveriam ser utilizados, como armas de alto potencial ofensivo, blindados, cercos e megaoperaçóes militares de invasão e ocupação, ainda que a utilização do aparato pudesse provocar tiroteios - os tais "confrontos" - e levar a "danos colaterais"; afinal, vivia-se (e vive-se) uma situação crítica, que tornaria "obrigatórias" medidas excepcionais.

Por outro, como afirmou o entáo porta-voz do Comando Conjunto e do Comando Militar do Leste, o coronel Carlos Frederico Gomes Cinelli, não seria possível acionar categorias do "direito de guerra" no Rio, pois a situação não poderia ser comparada a "operaçooes de guerra". Aqui é que a manifestação desse jogo nos permite apontar como a configuração assumida pela intervenção, bem como das GLOs, é delineada por um arranjo prático-discursivo que opera nas dobras do legal e do ilegal, do formal e do informal.

Em matéria produzida pelo Uol, em 28 de fevereiro de 2018, afirma-se que foi apurado que as Forças Armadas gostariam de ter "mais segurança" para agir nas atividades realizadas no espaço urbano, mas sem que as regras fossem flexibilizadas a ponto de configurar sua atuação nos marcos de normativas reguladoras de situaçóes definidas tradicionalmente como guerra, como a Convenção de Genebra (Kawaguti, 2018). Isso se materializaria na sanção presidencial ao Projeto de Lei 13.491/2017, que transferiu a competência de julgamento de crimes contra a vida cometidos por militares durante operaçóes de GLO da Justiça comum para a militar. O que se verifica, portanto, é que o esforço prático-discursivo aqui descrito ressalta justamente que a possibilidade de produção da guerra como modo de governo - sua normalização - existe apenas numa zona em que o legal e o ilegal se indeterminam, o que permite realizar "operaçóes de guerra" sem que elas sejam definidas como uma guerra padrão, de acordo com normas internacionais e seus protocolos (e as consequências decorrentes disto).

\section{A produção de alteridade radical: a territorializaçáo e corporificaçáo da guerra}

Tal como afirma Mbembe (2016, p. 135), as experiências de produção da guerra nas favelas do Rio de Janeiro nos colocam diante de processos de inscriçáo (territorialização), que implicam tanto " $a$ demarcação e afirmação de controles físicos, geográficos" quanto também morais, o que aponta para a produção 
contínua "de fronteiras, hierarquias, zonas e enclaves, mas igualmente a classificação de pessoas em diferentes categorias". Nesse sentido, para que essa maquinaria de guerra funcione, é fundamental a construção de uma alteridade radical, territorializada e racializada. No cenário que analiso nesse artigo, esse Outro da cidade, a imagem do medo, localiza-se no corpo favelado e em seus locais de moradia. ${ }^{19} \mathrm{~A}$ condição de possibilidade da demarcação territorial, racial e moral daqueles associados com a "imagem fantasmática do inimigo" (Gonzalo, 2017) na cidade é justamente a incessante repetiçáo dos enunciados performativos - de acordo com Silva (2000), na linha de Austin (1990) -, tais como aqueles relacionados à afirmação que associa violência e favelas, ou seja, a favela como um lugar ontologicamente violento.

Tal repetiçáo se verifica tanto na imprensa como nas declaraçóes das autoridades públicas. Em entrevista, o entáo ministro da Justiça, Torquato Jardim, logo após a decretação da intervenção no Rio de Janeiro, afirmou o seguinte:

Quantos eu preciso para a Rocinha? Não sei. Como você vai prevenir aquela multidáo entrando e saindo de todas as 700 favelas? Tem 1,1 milhão de cariocas morando em favelas. Desse 1,1 milhão, como saber quem é do seu time e quem é contra? (destaques meus). (Jardim, 2018)

Pouco tempo antes, em meados de 2017, o governo federal produziu e veiculou um vídeo, após o envio de tropas militares para atuar no Rio de Janeiro - como já destacado -, apresentando o que seriam as medidas de segurança adotadas. ${ }^{20}$ A construção das imagens reforça, pela repetição, a afirmação de como as tecnologias de produção da guerra necessariamente se articulam através da construção do Outro. Uma parte considerável da peça exalta as belezas e os pontos turísticos do Rio, destacando os bairros considerados nobres. As partes tidas como não tão nobres assim, periferias e favelas, têm uma aparição tímida, mas muito significativa: mostram-se militares entrando em favelas com suas armas e tanques, reforçando no imaginário coletivo a ideia de que aquele não só é o lócus primordial da violência que se espraia para o restante da cidade, como também que a única "solução" possível para os problemas existentes seria a produção da guerra.

Tal elaboraçáo não passa despercebida dos próprios moradores que, pelo inverso, nos permitem visualizar o funcionamento dessa estratégia discursiva:

Aqui eles tratam todo mundo como se fosse bandido, ou é mãe e pai de vagabundo, se é mulher nova é mulher de vagabundo, se é criança é filha de vagabundo. Tem $99 \%$ de morador, de trabalhador, mas eles acham que todo mundo é bandido. (Defensoria Pública do Estado do Rio de Janeiro, 2018) ${ }^{21}$

Não podemos compactuar com isso. A gente fica completamente sem defesa. Todo mundo é inimigo para esses caras. Crianças de 8 anos tendo que abrir mochila para ser revistada não pode ser. Inaceitável. (Torres, 2018)

Todos esses enunciados, tanto do ponto de vista de quem justifica a atuação dos aparatos de segurança nesses territórios quanto daqueles que são seus alvos preferenciais, nos permitem perceber e compreender como as favelas continuam sendo atualizadas como o lócus da violência - sobre o qual irão incidir estas diferentes tecnologias de controle e gestáo. Ou seja, as favelas continuam sendo produzidas como esse Outro, como essa alteridade radical que se apresenta como o elemento disruptivo da ordem social. Nesse sentido, é possível afirmar, a partir do rastreamento não só das inúmeras declaraçôes oficiais, mas também da operação material das forças de segurança, como as favelas e seus moradores são o alvo principal dessa "guerra assimétrica".

Como afirma Vianna (2019), esses corpos circunscritos por esses enunciados são "vivos-matáveis", e existiriam em "condição de irrealização contínua". Para a autora, eles seriam

evocados de maneira espectral quando se fala na necessidade de eliminá-los, formando um corpo coletivo e sem rosto definido que se materializa de súbito naqueles que foram (ou devem ser) alvo de snipers e drones, em uma fantasia de tons simultaneamente futuristas e nostálgicos. 
Portanto, essa desrealização provocada pela guerra só é possível porque ela se precipita em pessoas concretas, porque ela encarna certos sujeitos constituídos como uma alteridade radical - a partir da qual determinadas tecnologias de governo e formas de violência incidirão, sem que sejam consideradas danosas.

\section{A violência ordinária: tecnologias utilizadas e efeitos na vida cotidiana dos moradores de favelas}

Diante dessa configuração, mais do que se perguntar sobre o por quê de certas vidas serem matáveis, a questão fundamental é entender como se torna possível tomar uma vida como matável. Nesse sentido, formulam-se diferentes tecnologias para produzir a desrealizaçáo das vidas e das diferentes formas que esta possa assumir ao longo do tempo (Butler, 2006; Mbembe, 2016). Aqui, para certas populaçôes tornadas matáveis, impera a lógica do terror e do horror, ou seja, um intenso processo de desfazimento de seus horizontes possíveis de mundo.

Tendo em vista tais circunstâncias, é possível afirmar que há sujeitos que são levados a habitar regimes de medo, terror e horror, nos quais se produz, nos termos de Gonzalo (2017), um "regime espectral do horror", onde ganha relevância o artifício do inimaginável e do excesso. Nesse sentido, a capacidade de captura do poder se estende além do que pode ser compreendido como ameaça, transformando a irrealidade em algo real, a partir sobretudo da concepçáo de que se está diante de pessoas ou instituiçōes que podem fazer qualquer coisa a qualquer momento. Nessa angulação é que é possível pensar as chamadas "megaoperaçôes" como a tecnologia a partir da qual o horror se materializa e se expande continuamente em suas consequências na vida cotidiana, para além dos atos espetaculares.

\section{As megaoperaçóes}

As chamadas operaçôes policiais, ou incursóes, marcam historicamente o modo de atuaçáo do aparato policial nas favelas e periferias do Rio de Janeiro. Caracterizam-se por conjuntos de policiais que, a partir da justificativa do "combate ao tráfico de drogas", realiza investidas com o objetivo de "capturar bandidos e apreender drogas e armas". Em geral, essas operaçôes são marcadas por relatos de truculência, desrespeito, humilhações e violaçóes as mais variadas. Contudo, nos últimos anos, em função da normalizaçáo do confronto como a forma de realizaçáo da política de segurança pública, houve um incremento dessas açōes e muitas delas passaram a ser denominadas com o prefixo "mega": as "megaoperaçôes". Mais do que incursões pontuais de grupos de policiais, às vezes em poucas viaturas, essas intervençōes passaram a contar com aparatos cada vez maiores, incluindo-se aí o famoso equipamento de guerra "caveirão".

Esse processo de incremento material das forças de segurança, que se deu em função de investimentos cada vez maiores por parte do governo estadual (com apoio do governo federal), permitiu que se constituísse uma verdadeira maquinaria de guerra voltada para o "combate ao crime". As megaoperaçóes se tornaram comuns e, com o tempo, passaram a ter o reforço, ou serem articuladas a partir, das Forças Armadas, como foi o caso daquelas realizadas para preparar a instalação das UPPs.

Aponto que, com a intervenção federal, foi possível observar uma inflexão importante e significativa na mobilizaçáo dessa tecnologia, o que reforça o argumento central desse texto de que a guerra se transformou no modo mesmo de governar certas populaçōes. A grandiosidade das operaçōes realizadas naquele contexto foi capaz de extrapolar a própria ideia de "megaoperação" através da qual se articulavam as polícias locais, já que essas incursōes - em geral também muito custosas do ponto de vista financeiro - não apenas contam com aparatos imensos (número de efetivo, armamentos de grosso calibre, veículos blindados terrestres e aéreos), como também se caracterizam pela simultaneidade e intensidade com que acontecem em diferentes regiôes do estado. Portanto, essa simultaneidade e essa intensidade seriam duas dimensōes importantes para compreender o "legado" da intervenção federal no Rio.

Explorarei essa questáo um pouco mais adiante, mas adianto que a combinação dessas duas dimensóes permite justamente produzir como efeito não somente o atordoamento daqueles diretamente definidos como seus alvos preferenciais, dificultar ou mesmo 
impossibilitar a atuação de toda a rede de solidariedade, de militância e jurídica de apoio às pessoas habitantes dessas localidades.

De acordo com o relatório final do Observatório da Intervenção, durante todo o período da intervençáo federal ocorreram 711 operaçóes e 221 açóes de "patrulhamento monitoradas" em 296 locais do Rio de Janeiro. Ainda de acordo com o relatório, agosto foi o mês em que mais se observou a atuaçáo dos aparatos de segurança, quando ocorreram 109 operaçóes e 21 patrulhamentos. O levantamento também apontou que, de todas as operaçóes consideradas, 220 foram conjuntas, isto é, envolveram as forças locais de segurança e as Forças Armadas, totalizando 30,9\%.

Na imagem abaixo (Figura 1) é possível observar a distribuição das operaçōes no município do Rio de Janeiro:

As megaoperaçóes, marcadas pela simultaneidade e a intensidade, fizeram crescer também os tiroteios. A organizaçáo Fogo Cruzado, que tem feito o monitoramento dos tiroteios nos últimos anos no Rio de Janeiro e em Pernambuco, apontou que, durante a intervenção federal, ocorreram 8.613 tiroteios e disparos de armas de fogo, um aumento de 56,6\% em comparação ao mesmo período de 2017. Ou seja, os dados produzidos pela equipe do Fogo Cruzado nos permitem afirmar que, ao contrário do que o discurso oficial parecia fazer crer (de que a violência diminuía), tivemos um crescimento das situaçóes e circunstâncias de tensão e exposição à morte após a intervençâo e, principalmente, o incremento material das megaoperaçóes com a participaçáo das Forças Armadas. Ainda de acordo com a organização, a média diária de tiroteios aumentou de forma contínua: 25 em março; 26 em abril; 29 em maio; até que, em agosto, alcançou o patamar de 33 registros de tiroteios/disparos de arma de fogo por dia. Além disso, 60 tiroteios tiveram duraçáo de duas horas ou mais, totalizando 262 horas e 41 minutos de disparos contínuos, sendo que ao menos 31 dessas situaçóes decorreram das megaoperaçóes policiais/militares.

Observamos no gráfico abaixo (Figura 2) a quantidade de tiroteios ocorrida a cada mês no período da intervenção federal:

Como o mapa a seguir mostra (Figura 3), uma parte considerável das operaçôes se concentrou na Zona Norte e no subúrbio da capital fluminense, especialmente em favelas ou conjuntos de favelas, como o Alemão, Maré, Manguinhos e Jacarezinho. Portanto, a partir desse mapa é possível observar a constituição de uma verdadeira cartografia do terror nas favelas do Rio de Janeiro.

\section{Figura 1}

\section{Mapa do número e da localização das operaçóes policiais durante a intervençáo federal}

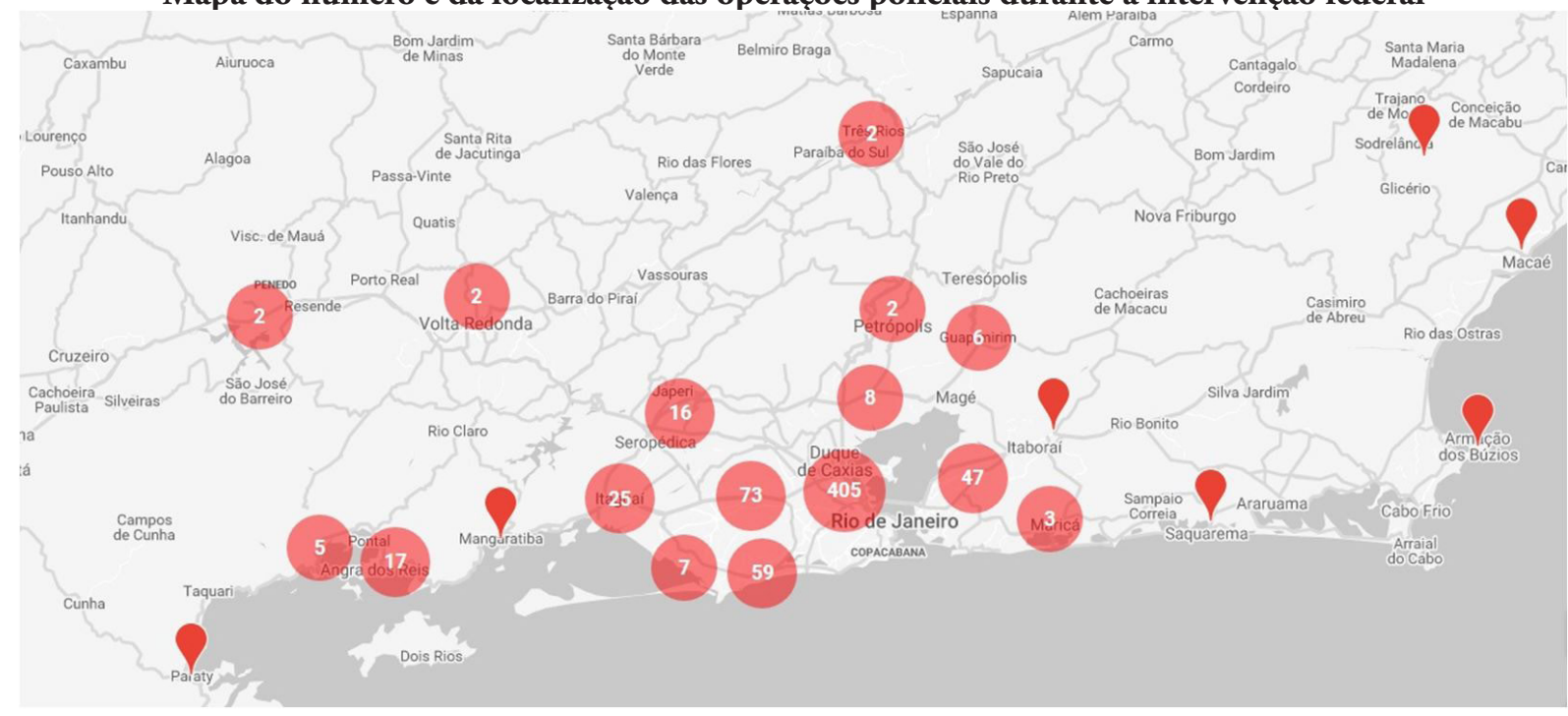

Fonte: Observatório da Intervenção 
Figura 2

Gráfico referente a tiroteios ocorridos durante a intervençáo federal

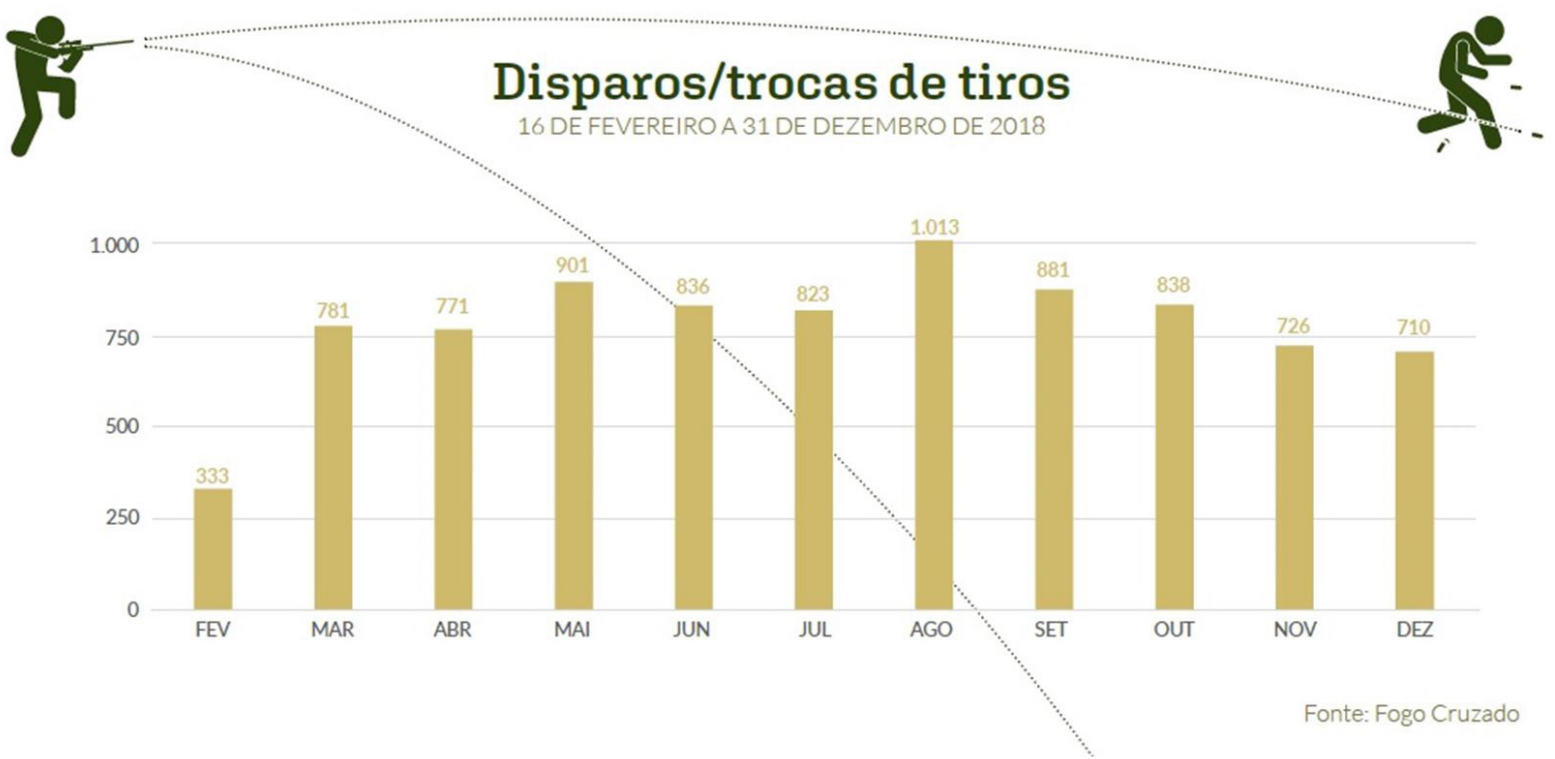

Fonte: Fogo Cruzado

Figura 3

Mapa da localização das megaoperaçóes policiais durante a intervenção federal

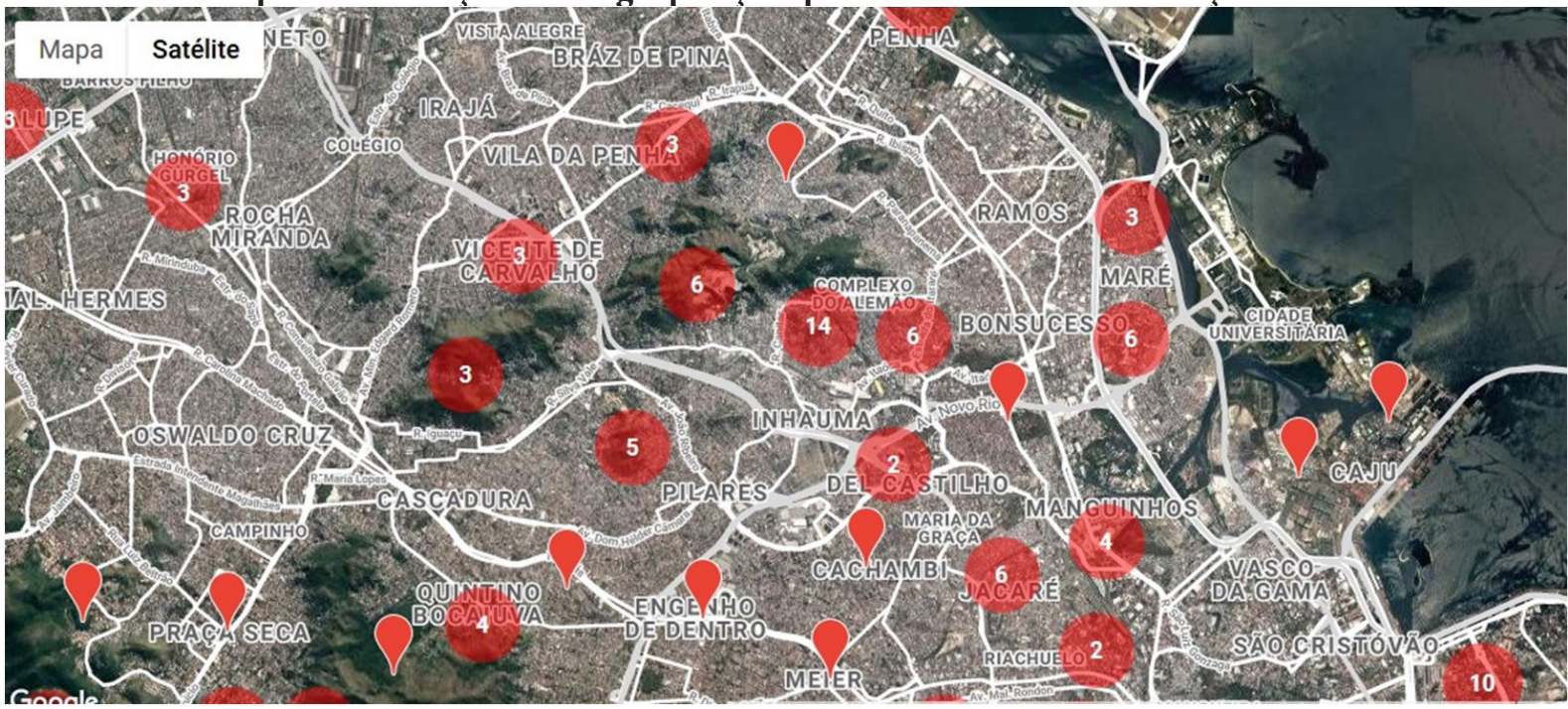

Fonte: Fogo Cruzado, 2018

Outra dimensão importante a ser destacada nesse cenário organizado pela produção da guerra é o aumento vertiginoso das chacinas após o início da intervenção. Em relatório produzido dois meses depois, o Observatório da Intervenção (Ramos, 2018, p. 14) apontou o que parecia ser uma tendência e uma característica que marcariam a intervençáo e o que se seguiu a ela: "A existência de vitimas múltiplas em episódios de intervençáo policial e de confronto de facçóes criminosas pode estar se tornando uma marca deste novo momento do Rio sob intervenção". Ao final da intervenção, foram contabilizadas 54 chacinas, 
nas quais 216 pessoas foram mortas, o que representa $63,6 \%$ a mais do que no mesmo período do ano de 2017. A distribuição dessa contabilidade do terror (ou dessa necrocontabilidade, nos termos de Adriana Vianna) ficou da seguinte forma: o Rio de Janeiro registrou 19 chacinas, seguido de Duque de Caxias, com seis e Belford Roxo, com cinco.

\section{Teatralizaçáo do controle: rotina e espetáculo}

Os dados discutidos acima nos permitem compreender as megaoperaçóes - que contavam com um contingente de milhares de agentes articulando-se a partir de dois eixos, um relacionado à forma assumida por essa tecnologia e outro como consequência. Em primeiro lugar, é possível afirmar que as megaoperações combinam duas formas de atuação das forças estatais: uma ação espetacular, marcada pela grande quantidade de pessoas e maquinários de guerra envolvidos (incluindo helicópteros); e o fato de haver um esforço para transformar tais iniciativas em algo permanente, em uma rotina de funcionamento dos aparatos de segurança. Tais ações, espetaculares ou não, de alguma forma diziam respeito à demonstração de força pelo próprio aparato estatal e, nesse sentido, tanto do ponto de vista material quanto do simbólico, buscava-se reforçar a ideia de que o recurso legítimo à violência era uma prerrogativa do Estado nacional.

Em segundo lugar, é possível afirmar que as megaoperações produzem verdadeiras "geografias de terror" (Oslender, 2004), isto é, transformam determinados lugares e regióes em "paisagens de medo" com certas articulaçôes espaciais que, de alguma maneira, tendem a romper de forma dramática, e recorrentemente imprevisível, as relaçôes sociais locais (Oslender, 2004). Como o autor afirma, ainda, o terror é uma ferramenta de controle social; sua aplicação sistemática torna possível a destruição do tecido social das localidades à quais está direcionado, levando à constituiçáo de um sentido de medo generalizado entre os habitantes daquele território. E tal como afirma Gonzalo (2017), o que é ainda mais significativo dessas configuraçóes atravessadas pelo terror é o modo pelo qual o próprio sujeito se desfaz - justamente por ser levado a uma geografia articulada para causar dano, dor e sofrimento.
Nessa configuração, cabe compreender como certas formas de violência e imposição do terror e do horror produzem a irrealidade (estes corpos e lugares que não existem e, portanto, podem desaparecer/ser eliminados). Esta irrealidade se transforma na própria pré-condição para o exercício de uma violência que não será considerada danosa. Nesse sentido, a mobilização das megaoperaçóes como tecnologia de governo nos aponta para formas de gestão da impossibilidade da vida (ou de certas vidas, vistas como indignas de serem vividas). Nos termos de Butler, portanto, trata-se de uma tecnologia governamental articulada a partir de uma "violência desrealizadora", que busca fazer eliminar física e simbolicamente certas vidas e formas de existir. Ainda de acordo com a autora, associada a essa forma de violência, delineia-se a conformação do que ela chama de "vidas destrutíveis", isto é, de vidas que não são passíveis de serem vividas, já que nem mesmo são consideradas vidas. São formas de vida, modos de existir que estáo expostos continuamente à destruição e à morte, cuja eliminação não pode e não vai ser lamentada justamente por não serem consideradas vidas, um modo de existir legítimo, reconhecido enquanto tal.

Com efeito, a "violência desrealizadora", ainda que não extermine de uma única vez um determinado conjunto de pessoas ou modos de existir, atentaria de forma direta contra as formas de viver, como afirma Gonzalo (2017), justamente porque sua característica fundamental é produzir uma vida constantemente exposta. A produção constante da exposição à morte (mas também à precariedade/provisoriedade) é a própria condição de possibilidade para a constituição do aparato estatal e para a conformaçáo de uma forma de governar cujo núcleo principal é a guerra.

Tal circunstância, delineada pela guerra, faz com que as rotinas de vida sejam dilaceradas continuamente por choques violentos, o que desarticula o cotidiano e impossibilita (ou dificulta) inscrever a própria vida num horizonte de previsibilidade. Esses choques produzidos pelas megaoperaçóes constituem e têm feito ampliar a incerteza - especialmente sobre a continuidade da própria vida - como a dimensão caracterizadora dessas trajetórias. Eles abalam não só a certeza sobre a permanência do mundo à volta, mas também o próprio autoconhecimento, isto é, o 
"quem sou eu?" em meio a esse turbilhão incessante de acontecimentos terríveis.

Essas megaoperaçóes eram marcadas também por um conjunto outro de violências, que não só aquelas que atentam diretamente contra a vida. Como afirmei acima, essa tecnologia de terror produzia e produz uma constante exposição, e se configura a partir de elementos que buscam desarticular igualmente tanto as rotinas de vida quanto a própria autoidentidade. De acordo com a "tipologia de violaçóes" produzida pela Ouvidoria da Defensoria Pública do Estado do Rio de Janeiro (como apresentado na Figura 4 abaixo), podemos observar que as açóes espetaculares e as explosóes violentas decorrentes das megaoperaçóes eram atravessadas por um conjunto muito variado de técnicas de produção do terror.
No relatório parcial do Circuito Favelas por Direitos, ${ }^{22}$ afirma-se o seguinte em relação às violaçôes de direitos:

Os números de homicídios e as chacinas têm ganhado visibilidade na imprensa com a divulgação de dados estatísticos e de casos específicos. As outras violaçóes de direitos que acontecem durante as operaçôes de segurança não ganham a mesma visibilidade pública (Defensoria Pública do Estado do Rio de Janeiro, 2018a).

Nesse sentido, o relatório buscava chamar a atenção para o fato de que as megaoperaçóes deixavam um rastro de medo e horror, atingindo em cheio a rotina de vida das populaçóes moradoras destas localidades.

Figura 4

Tipologia das violaçóes de direitos humanos durante a intervençáo federal

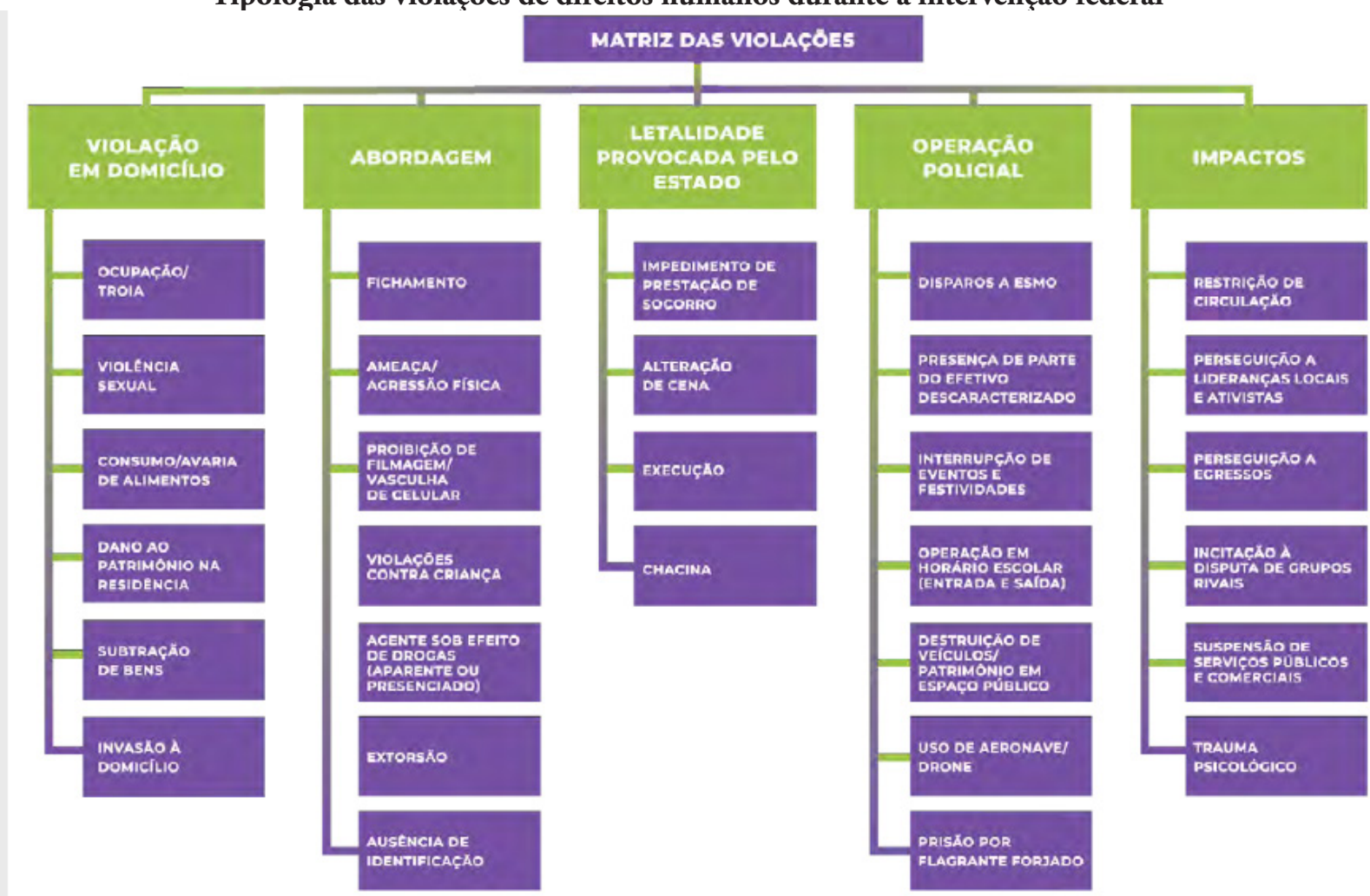

Fonte: Relatório Parcial do Circuito Favelas por Direitos do Núcleo de Direitos Humanos da Defensoria Pública do Rio de Janeiro (2018a). 
É interessante discutir aqui não somente a sobreposição de diferentes mecanismos violentos de controle, mas também a diferença em relação à publicizaçáo dos mesmos, ainda que afetem a rotina de vida dos moradores igualmente. Parece evidente que os crimes contra a vida chamam mais a atenção dos moradores dessas localidades e do restante da população; contudo, é importante ressaltar as práticas rotineiras de desfazimento da vida social local a partir de uma pletora de açóes estatais que vão se acumulando no cotidiano e tornando a experiência de ali viver cada vez mais difícil.

Se a morte figura no horizonte como o limite sempre ultrapassável da existência possível, a ela se junta uma produção difusa e cotidiana de práticas que vão minando as forças e energias daqueles que insistem em existir de alguma forma. Nesse sentido, à eliminação física - a dimensão trágica da máquina violenta de guerra - somam-se abordagens truculentas, arrombamentos, estupros e também ataques de natureza moral, como xingamentos, desqualificaçóes e ofensas. É isso que vemos na seguinte fala de uma moradora, extraída do mesmo relatório (Defensoria Pública do Estado do Rio de Janeiro, 2018a, p. 7): "Isso não está certo. Eles têm que fazer o trabalho deles, mas não podem nos humilhar". O que esse conjunto de violações parece nos mostrar, quando colocado em perspectiva, é que a violência desestruturadora da vida sempre se articula a partir de um duplo: não basta provocar uma marca no corpo, supliciá-lo; é necessário também humilhá-lo, fazendo com que desconfie de si mesmo, de suas capacidades e potências.

Como continuar vivendo e de quais formas é uma questão que tanto os moradores atravessados por essas tecnologias de terror quanto nós, pesquisadores e cidadáos em geral, devemos nos colocar - no sentido de imaginar uma experiência de cidade que possa efetivamente se realizar a partir de parâmetros de reconhecimento e de acesso a bens e serviços de cidadania, dignidade e respeito.

\section{Quais resistências?}

Nessa última seçāo, buscarei traçar algumas rápidas reflexóes (que ainda demandam dimensionamento empírico melhor) acerca das resistências, num cenário marcado por sufocamento, asfixia e desestruturação dos modos de vida. Meu objetivo é compreender as condiçóes de possibilidade nas quais formas de (re) existir são inventadas e experimentadas em contextos de vida drasticamente abalados. Algumas perguntas se fazem pertinentes: como contornar e/ou viver em meio à destruição? Quais estratégias acionar ou criar para impedir que a destruição acabe definitivamente com qualquer linha de vida?

A consideração, aqui, é que tornar a vida habitável faz parte das possibilidades do que poderia ser denominado de resistência em situaçôes limite e de exposição à morte. Nesse sentido, descreverei uma situaçáo que pude observar durante uma das rodadas de visita do Circuito Favelas por Direitos realizada pela Defensoria Pública, e que me parece interessante para compreender esse processo de (re) habitar a vida em meio à destruiçáo.

Em uma das visitas do Circuito, realizada num dos conjuntos de favelas da cidade, na roda de conversa que se formou logo depois que chegamos ao local, chamou-me a atençáo a fala de uma moradora de uma favela da região. Ela ponderou que muitas vezes, quando outros se referem a esses territórios, a única dimensão destacada é a da violência. Ela ressaltou que, embora este seja um aspecto importante a ser considerado, não seria suficiente para entender o que se passa no cotidiano local. A partir daí, ela discorre sobre a importância de falar também da vida, sobre a afirmaçâo da vida em meio à situaçáo de violência que atravessa o cotidiano dos moradores.

Logo depois, dividimo-nos em dois grupos. Do grupo do qual eu fazia parte, participaram moradores da regiáo e uma das lideranças de uma ONG atuante na área. Fazia um sol escaldante e foi muito cansativo andar pelas ruas no trecho de uma das favelas que ficou sob nossa responsabilidade. Esse foi um momento em que pudemos encontrar alguns moradores e conversar com eles sobre a situaçáo local, especialmente sobre as operações das forças de segurança. Contudo, com a frase dita pela moradora que mencionei há pouco ressoando quase que como um chamado, uma situação me atraiu a atenção enquanto caminhávamos por ruas e vielas, em meio às perguntas sobre possíveis violaçôes cometidas pelas açôes rotineiras das polícias: notei como, diante de diversas casas, havia grupos de 
crianças (mas também de adultos) que se refrescavam em piscinas, muitas delas improvisadas. Para além de um olhar que estetiza a "alegria da/na pobreza", gostaria de chamar atenção não só para o acesso restrito, ou limitado, a espaços de lazer no interior (e mesmo fora) da localidade, mas também para como a vida pulsava, ali, de alguma forma (ainda que recorrentemente atravessada por explosóes de violência). Mesmo em meio aos relatos de terror, que os participantes da equipe de visita insistiam em trazer à tona (apesar da recusa de muitos em falar), as pessoas mantinham suas vidas e as crianças se divertiam em suas piscinas feitas em caixas de água cujo uso fora ressignificado. Ou seja, não estávamos apenas em um "espaço de morte", mas também de afirmação da vida.

Nesse momento, e recordando de outras falas e cenas que recolhíamos em notas e na memória, e me apoiando nas reflexôes de Pelbart (2008), fui me dando conta de como é necessário, quando falamos do terror, não deixar subsumir (tal como na exigência feita pela moradora/militante) a dimensão da afirmação da vida. Como afirma o filósofo, ao mesmo tempo em que descrevemos e buscamos compreender os mecanismos e estratégias agenciadas pelo poder sobre a vida (que, em casos como o das favelas, é um poder de morte, de fazer morrer), devemos estar atentos aos inúmeros esforços, muitas vezes microesforços, realizados pelas pessoas em seu cotidiano para viver, ou seja, o poder da vida. Ali onde aparentemente imperariam apenas terror e medo, se vislumbram linhas de existência que afirmam - num ato simples como o de se refrescar do calor excessivo em uma piscina na rua - a própria vida, a possibilidade da vida.

\section{Conclusóes}

Diferentemente do que afirma Foucault (2008), não basta a consideração de que um conflito imanente constitui e atravessa a sociedade, mas, fundamentalmente, de como certas figuraçóes deste conflito se materializam no governo pela morte produzido pela guerra. Historicamente, o conflito se realiza, em formaçóes sociais como a brasileira e particularmente no espaço urbano carioca, a partir de uma guerra permanente contra certas populaçóes.
Seria possível afirmar que lidamos com certa ontologia política - que caracterizaria este tipo de formaçáo social - constituída a partir da destruição ou da possibilidade de destruição de certos modos de existir na cidade.

Nesse sentido, a configuração constituída pela atuação dos aparatos de segurança em diferentes momentos, nos últimos anos, especialmente a partir da normalização da guerra pela intervenção federal, caracteriza-se a partir da constataçáo de que a força do poder se exerce pelo poder da força. Ainda que saibamos que o poder pode assumir diferentes facetas em seus modos práticos de realização, gostaria de destacar que, no caso de sua manifestação nas formas de governo dos pobres urbanos no Rio de Janeiro, ela necessariamente se constitui a partir do uso indiscriminado da força, da violência e da produção do terror, do horror e da morte.

\section{Notas}

1 Compreendo "ordem urbana” como um determinado arranjo social, político, cultural e econômico composto pelo atravessamento e a combinação de diferentes fluxos constitutivos da vida urbana. Por governo, seguindo a linha foucaultiana, modalidades de gestão e condução de condutas que, no caso do presente artigo, assumem uma forma militarizada, bio/necropolítica. Desta forma, portanto, entendo que, no caso em análise, a "ordem urbana”, sua gestão, assume, cada vez mais, contornos bio/necropolíticos. Assim, as "políticas", ou ações especificamente direcionadas ao governo das pessoas, articulam-se a partir de mecanismos militarizados de controle.

2 O que se torna mais interessante e trágico, ao mesmo tempo, é que não importa qual a situação política e social do momento (vista como positiva, "eufórica" ou de decadência e declínio): em todas essas ocasiōes é possível visualizar a atualização de práticas de controle e gestão populacional cada vez mais militarizadas.

3 "Pelo menos 13 pessoas morreram em açôes policiais em quatro dias no Rio", https://g1.globo.com/rj/rio-de-janeiro/ noticial2019/05/07/pelo-menos-13-pessoas-morreram-emacoes-policiais-em-tres-dias-no-rio.ghtml.

4 Observando o mesmo cenário, Rocha (2018) afirma que a intervenção federal representa a radicalização da militarização. 
5 Nesse mesmo campo de diálogo, Telles (2019) ressalta que a violência se tornou uma técnica de poder e também um modo de governo. Para a autora: "sem eufemismos, é o que está posto e exposto na 'autorização para o abate' que quer Wilson Witzel".

6 O Observatório da Intervenção foi uma iniciativa promovida pelo Centro de Estudos de Segurança e Cidadania da Universidade Candido Mendes. Seu objetivo foi "acompanhar e divulgar os desdobramentos, os impactos e as violaçóes de direitos decorrentes da intervenção federal no estado do Rio de Janeiro".

7 O Monitor é uma parceria do site G1 com o Núcleo de Estudos da Violência da USP e o Fórum Brasileiro de Segurança Pública para monitorar a incidência e as estatísticas dos crimes violentos no país.

8 Sobre a emergência e ocaso das UPPs, ver Menezes (2015). Sobre a relação entre militarização e expansão da cidadania no contexto das UPPs ver Fleury (2012).

9 Além da expansão crescente e intensa das milícias.

10 E também de um redirecionamento dos objetivos das forças de segurança no contexto recente de crise econômica. De acordo com Grillo e Hirata (2019), as "operaçôes policiais e militares têm sido cada vez mais direcionadas à proteção patrimonial em detrimento da defesa da vida". Os autores sustentam, ainda, que "parte do aumento da letalidade decorrente de intervenção policiallmilitar está relacionado ao empenho das forças da ordem em garantir a circulação e posse de riquezas".

11 Reguladas pela Constituiçáo Federal, em seu artigo 142, pela Lei Complementar 97, de 1999, e pelo Decreto 3897, de 2001, "as operaçóes de GLO concedem provisoriamente aos militares a faculdade de atuar com poder de polícia até o restabelecimento da ordem". No início de 2014, o Ministério da Defesa publicou o Manual de GLO, confeccionado por assessores civis e militares, com o objetivo de padronizar as rotinas e servir de instrumento educativo e de doutrinação para as forças preparadas para atuar nesse tipo de ação.

12 Como se afirmou à época dos acontecimentos, tal iniciativa do governo federal atuaria como um experimento do Plano de Segurança Pública lançado no início daquele ano, após dezenas de mortes ocorridas em presídios em vários estados do país.

13 Ver também, sobre as relaçôes entre os entes federativos, a institucionalização e conflitos no campo da "segurança pública”: Lima, Sinhoretto e Bueno (2015); Lima, Silva e Oliveira (2013).

14 Aqui é importante mencionar que a decisão pelo cerco militar se deu na ocasiáo em que um grande evento se realizava na cidade: o Rock in Rio. Como a Rocinha fica localizada acima de uma importante via de acesso entre a Zona Sul e a Zona Oeste (local do evento), havia a preocupaçáo de que os tiroteios incessantes pudessem interromper o fluxo de pessoas para o evento.

15 Ministério da Defesa, www.gov.br/defesa/pt-br/assuntos/ exercicios-e-operacoes/garantia-da-lei-e-da-ordem.

16 Um argumento menos debatido, mas que parece compor o conjunto de motivações para a intervenção, seria, segundo Grillo e Hirata (2019), a "pressão política exercida por entidades empresariais que reivindicam maior empenho das autoridades públicas no combate aos crimes contra o patrimônio, que cresceram significativamente nos últimos anos".

17 Os autores ainda afirmam que qualquer evento ou situação vista como problemática tem potencial para se tornar uma emergência, ocasião a partir da qual um conjunto de danos pode emergir.

18 Numa argumentação próxima à apresentada neste texto, Leite e Birman (2018) afirmam que "estar Estar em guerra significa, no Rio de Janeiro de hoje, não mais combates pontuais a criminosos através das incursóes dos PMs às favelas, em que a proteçấo aos moradores nunca foi considerada, mas uma nova modalidade de guerra, assimétrica, na medida em que, doravante, os inimigos incluem, explicitamente, a população do lugar".

19 A identificaçấo dos corpos favelados e seus territórios como a representação da violência, do mal e do perigo em nossas cidades já foi abordada por variados autores, por meio das chaves analíticas mais distintas. Entre outros, destaco Machado da Silva (2008, 2010); Machado da Silva e Leite (2016a, 2016b); Misse (2008, 2010); Leite (2000, 2012); Caldeira (2003); e Zaluar (1985). Estendendo um pouco mais a linha histórica, podemos observar como a construção dessa imagem do perigo expressa por quem habita determinados territórios já era um dispositivo importante de controle no período do Império e início da República (Chalhoub, 1986, 1996).

20 "Para Exército, não há guerra no Rio, mas vídeo do governo mostra tanques em favelas". Jornal Extra, 31 ago. 2017

21 Relato extraído do Relatório Final do "Circuito Favelas por Direitos”, da Defensoria Pública do Rio de Janeiro.

22 A ação da Ouvidoria da Defensoria Pública consiste numa “iniciativa que reúne órgãos públicos e organizaçôes civis, capazes de promover uma escuta qualificada e permanente - durante a Intervenção Federal na Segurança Pública - em favelas da região metropolitana do Rio de Janeiro". Tal iniciativa percorreu e ouviu moradores de trinta favelas da regiâo metropolitana no Rio de Janeiro durante a intervenção. 


\section{REFERÊNCIAS}

ADEY, Peter; ANDERSON, Ben \& GRAHAM, Stephen. (2015), "Introduction: Governing Emergencies: Beyond Exceptionality". Theory, culture and society, 32, 2:3-17. Disponível em https://journals.sagepub.com/doi/ abs/10.1177/0263276414565719?journalCode=tcsa, consultado em 10/07/2020.

AGAMBEN, Giorgio. (2007), Homo saccer I. O poder soberano e a vida nua. Belo Horizonte, Editora UFMG.

ARAUJO, Fábio. (2014), Das "técnicas" de fazer desaparecer corpos. Rio de Janeiro, Lamparina.

AUSTIN, John Langshaw. (1990), Quando dizer é fazer: palavras e ação. Porto Alegre, Artes Médicas.

AZEVEDO, Lena \& FAULHABER, Lucas. (2015), SMH 2016: remoçôes no Rio de Janeiro Olímpico. $1^{\text {a }}$ ed., Rio de Janeiro, Mórula.

BIRMAN, Patrícia; LEITE; Márcia P.; MACHADO, Carly \& SÁ CARNEIRO, Sandra de (org.). (2015), Dispositivos urbanos e trama dos viventes: ordens e resistências. Rio de Janeiro, Editora FGV.

BRASIL. Ministério da Defesa. (2020). Garantia da Lei e da Ordem. Disponível em www.defesa.gov. br/exercicios-e-operacoes/garantia-da-lei-e-daordem, consultado em 16/07/2020.

BRASIL. Ministério da Defesa. (2018), Plano Estratégico do Gabinete de Intervenção Federal (GIF). Disponível em http://www2.planalto.gov. $\mathrm{br} / \mathrm{mandatomicheltemer/acompanhe-planalto/}$ noticias/2018/06/plano-estrategico-gif.pdf. Consultado em 10/07/2020.

BUTLER, Judith. (2006), Vida precária: el poder del duelo y la violência. Buenos Aires, Paidós.

CALDEIRA, Teresa Pires do Rio. (2003), Cidade de muros: crime, segregação e cidadania em São Paulo. São Paulo, Edusp.

CHALHOUB, Sidney. (1996), Cidade febril: cortiços e epidemias na Corte Imperial. São Paulo, Companhia das Letras.

CHALHOUB, Sidney. (1986), Trabalho, lar e botequim: o cotidiano dos trabalhadores no Rio de Janeiro na Belle Epoque. São Paulo, Brasiliense.
DAS, Veena. (2007), Life and words: violence and the descent into the ordinary. California: University of California Press.

DAS, Veena \& POOLE, Deborah. (2004), Anthropology in the Margins of the State. Nova Delhi, Oxford University Press.

DEFENSORIA PÚBLICA DO ESTADO DO RIO DE JANEIRO. (2018), Circuito de favelas por direitos. Relatório.

DEFENSORIA PÚBLICA DO ESTADO DO RIO DE JANEIRO. (2018a), Relatório parcial do Circuito de Favelas por Direitos. Disponível em: http://sistemas.rj.def.br/publico/sarova.ashx/ Portal/sarova/imagem-dpge/public/arquivos/ Relatorio_Circuito_Favelas_Final.pdf. Consultado em 10/07/2020

DEFENSORIA PÚBLICA DO ESTADO DO RIO DE JANEIRO. (2018b), Relatório final do Circuito de Favelas por Direito. Disponível em: http://sistemas.rj.def.br/publico/sarova.ashx/ Portal/sarova/imagem-dpge/public/arquivos/ Relato\%CC\%81rio_Final_Circuito_de_Favelas_ por_Direitos_v9.pdf. Consultado em 10/07/2020.

FARIAS, Juliana. (2014), Governo de Mortes: uma etnografia da gestão de populaçóes de favelas no Rio de Janeiro. Tese de Doutorado, Programa de Pós-Graduação em Sociologia e Antropologia, Instituto de Filosofia e Ciências Sociais, UFRJ, Rio de Janeiro.

FLEURY, Sônia. (2012). Militarização do social como estratégia de integração - o caso da UPP Santa Marta. Sociologias, Porto Alegre, n ${ }^{\circ} 30$, p. 194-222. Disponível em: https://seer.ufrgs. br/sociologias/article/view/30079

FOGO Cruzado - dados de tiroteios no Rio de Janeiro e Recife. (2018), Mapa de localização das megaoperações durante a intervenção federal.

FOUCAULT, Michel. (2008), Em defesa da sociedade. São Paulo, Martins Fontes.

GODOI, Rafael. (2017), Fluxo em Cadeia. As Prisóes em São Paulo na Virada dos Tempos. São Paulo, Boitempo.

GONZALO, Ignacio Mendiola. (2016), “El dispositivo de la captura: espacios y cuerpos bajo el signo de la excepcionalidade". Athenea Digital, 16, 
1:83-111. DOI: https://doi.org/10.5565/rev/ athenea.1739

GONZALO, Ignacio Mendiola. (2017), “De la biopolítica a la necropolítica: la vida expuesta a la muerte". Eikasia: Revista de Filosofia, 75:219248. Disponível em http://www.revistadefilosofia. org/75-11.pdf, consultado em 10/07/2020.

GRAHAM, Stephen. (2016), Cidades sitiadas: o novo urbanismo militar. São Paulo, Boitempo Editorial.

GRILLO, Carolina \& HIRATA, Daniel. (2019), Roubos, proteçáo patrimonial e letalidade no Rio de Janeiro. Rio de Janeiro: Fundação Heinrich Böll.

GUTERRES, Anelise dos Santos. (2014), A resiliência enquanto experiência de dignidade: antropologia das práticas politicas em um cotidiano de lutas e contestaçóes junto a moradoras ameaçadas de remoção nas cidades sede da Copa do Mundo 2014. Tese de Doutorado. PPGAS/Universidade Federal do Rio Grande do Sul, Porto Alegre.

JARDIM, Torquato. (2018), “Não há guerra que não seja letal'", diz ministro da Justiça sobre intervenção no Rio”. Estado de Minas, 20 fev. (Política). Disponível em https://www.em.com. br/app/noticia/politica/2018/02/20/interna_ politica,938791/nao-ha-guerra-que-nao-sejaletal-diz-ministro-da-justica.shtml, consultado em 10/07/2020.

KAWAGUTI, Luis. (2018), “As Forças Armadas podem atirar para matar durante a intervenção no Rio?”, Uol Notícias, 28 fev. Disponível em https://noticias.uol.com.br/cotidiano/ultimasnoticias/2018/02/28/as-forcas-armadas-podematirar-para-matar-durante-a-intervencao-no-rio. htm, consultado em 10/07/2020.

LEITE, Márcia. (2000), "Entre o individualismo e a solidariedade: dilemas da política e da cidadania". Revista Brasileira de Ciências Sociais, 15 (44):73-90.

LEITE, Márcia. (2012), “Da 'metáfora da guerra' ao projeto de 'pacificação': favelas e políticas de segurança pública no Rio de Janeiro”. Revista Brasileira de Segurança Pública, 6:374.

LEITE, Márcia; BIRMAN, Patrícia. (2018), "Rio e São Paulo: categorias emaranhadas e relativização de seus sentidos", in J. Barros; A. Dal'Bó \& C. Rizek (org.), Os limites da acumulação, movimentos e resistência nos territórios. $1^{\text {a }}$ ed., São Carlos, IAU/USP.

LEMÓES, Tiago. (2017), De vidas infames à máquina de guerra: etnografia de uma luta por direitos. Tese de Doutorado, Antropologia Social, Universidade Federal do Rio Grande do Sul, Porto Alegre.

LIMA, Renato Sérgio de; SINHORETTO, Jacqueline \& BUENO, Samira. (2015), "A gestão da vida e da segurança pública no Brasil". Sociedade e Estado, 30:123-144. DOI: http://dx.doi.org/10.1590/ S0102-69922015000100008.

LIMA, Renato Sérgio; SILVA, Guilherme Amorim Campos \& OLIVEIRA, Priscilla Soares. (2013), "Segurança pública e ordem pública: apropriação jurídica das expressóes à luz da legislação, doutrina e jurisprudência pátrias”. Revista Brasileira de Segurança Pública, 7, 1:58-83.

MACHADO DA SILVA, Luiz Antonio. (2008), Vida sob cerco: violência e rotina nas favelas do Rio de Janeiro. Rio de Janeiro, Nova Fronteira.

MACHADO DA SILVA, Luiz Antonio. (2010), "Violência urbana, segurança pública e favelas: o caso do Rio de Janeiro". Cadernos CRH, Salvador, 23, 59:283-300.

MACHADO DA SILVA, Luiz Antonio \& LEITE, Márcia Pereira. (2016a), "Violência, crime e polícia: o que os favelados dizem quando falam desses temas?", in L. A. Machado da Silva (org.), Fazendo a cidade: trabalho, moradia e vida local entre as camadas populares urbanas, Rio de Janeiro, Mórula Editorial, 1:255-282.

MACHADO DA SILVA, Luiz Antônio \& LEITE, Márcia Pereira. (2016b), "Circulação e fronteiras no Rio de Janeiro: a experiência urbana de jovens moradores de favelas em contextos de pacificação”, in L.A. Machado da Silva (org.), Fazendo a cidade: trabalho, moradia e vida local entre as camadas populares urbanas, Rio de Janeiro, Mórula Editorial, 1:326-343.

MAGALHÁES, Alexandre. (2019), Remoçôes de favelas no Rio de Janeiro: entre formas de controle e resistências, Curitiba, Appris.

MALLART, Fábio. (2019), Findas linhas: circulaçôes e confinamentos pelos subterrâneos de São Paulo. Tese de doutorado, Programa de Pós-Graduação 
em Sociologia, Faculdade de Filosofia, Letras e Ciências Humanas da Universidade de São Paulo. MARTÍN, María. (2017), "Temer autoriza Forças Armadas no Rio, mas ministro adverte: 'Não esperem milagres"'. El País Brasil, 28 jul. Disponível em https://brasil.elpais.com/brasil/2017/07/28/ politica/1501264807_474459.html, consultado em 10/07/2020.

MBEMBE, Achille. (2016), "Necropolítica”. Arte \& Ensaios, 32:124-151. Disponível em https:// revistas.ufrj.br/index.php/ae/article/view/8993, consultado em 10/07/2020.

MENEZES, Palloma. (2015), Entre o "fogo cruzado" e o "campo minado": uma etnografia do processo de "pacificação" de favelas cariocas. Tese de doutorado, Instituto de Estudos Sociais e Políticos, Universidade do Estado do Rio de Janeiro, Rio de Janeiro.

MISSE, Michel. (2008), "Sobre a acumulaçăo social da violência no Rio de Janeiro". Civitas, 8:371-385.

MISSE, Michel. (2010), "Crime, sujeito e sujeição criminal. Aspectos de uma contribuição analítica sobre a categoria bandido". Lua Nova, 79:15-38.

OLIVEIRA, João Pacheco. (2014), "Pacificaçẫo e tutela militar na gestão de populaçôes e territórios". Mana, 20, 1:125-161.

OSLENDER, Ulritch. (2004), "Des-territorialización y desplazamiento forzado en el Pacífico colombiano: la construcción de geografias de terror". Seminario Internacional 'Des) Territorialidades y (no) lugares', INER, Medellín, 4-6 nov. Disponível em https://juliocerubio.jimdo.com/app/ download/10071026371/DES-TERRITORIA LIZACION+GEOGRAFIAS+DEL+TERROR. pdf?t=1551973966, consultado em 10/07/2020.

PELBART, Peter Pál. (2008), "Poder sobre a vida, potência da vida". Lugar Comum, 17:33-43. Disponível em http://uninomade.net/wp-content/ files_mf/1 13003120907Poder\%20sobre\%20 a\%20vida\%20pot\%C3\%AAncia\%20da\%20 vida\%20-\%20Peter\%20P\%C3\%A11\%20Pelbart. pdf, consultado em 10/07/2020.

PERES, Úrsula Dias \& BUENO, Samira. (2013), Pacto federativo e financiamento da segurança pública no Brasil, in G. Mingardi (org.), Política de segurança: os desafios de uma reforma, Sáo Paulo: Fundação Perseu Abramo, 1:125-144.

RAMOS, Silvia (coord.). (2018), À deriva: sem programa, sem resultado, sem rumo. Rio de Janeiro: Observatório da Intervençăo/CESec, abril.

ROCHA, Lia de Mattos. (2018), "Democracia e militarização no Rio de Janeiro: 'pacificação', intervenção e seus efeitos sobre o espaço público", in M. P. Leite; L. M. Rocha; J. Farias \& M. B. Carvalho (org.), Militarização no Rio de Janeiro: da pacificaçãa à intervenção, Rio de Janeiro, Mórula Editorial, coleção Engrenagens Urbanas.

RUI, Taniele \& FELTRAN, Gabriel. (2015), "Guerra e Pacificação: palavras-chave do conflito urbano contemporâneo". Nota do Comitê Migraçôes e Deslocamentos da Associação Brasileira de Antropologia, Brasília, ABA. Disponível em http:// www.portal.abant.org.br/images/Noticias/Nota sobre_Guerra_e_Pacifica\%C3\%A7\%C3\%A3o. pdf, consultado em 10/07/2020.

RUI, Taniele; MARTINEZ, Mariana \& FELTRAN, Gabriel. (2016), Novas faces da vida nas ruas, São Carlos, Edufscar.

RUI, Taniele. (2014), Nas tramas do crack: etnografia da abjeção. São Paulo, Terceiro Nome (coleção Antropologia Hoje).

SAFATLE, Vladimir. (2016), "A crise é um modo de governo", Folha de S. Paulo, 10 jun</newsp >.

SANJURJO, Liliana; FELTRAN, Gabriel. (2015), Sobre lutos e lutas: violência de estado, humanidade e morte em dois contextos etnográficos. Ciência e Cultura, v. 67, p. 40-45.

SILVA, Tomaz Tadeu. (2000), Identidade e diferença, Rio de Janeiro, Editora Vozes.

SOUZA LIMA, Antonio Carlos de. (1995), Um grande cerco de paz: poder tutelar, indianidade e formação do Estado no Brasil. Petrópolis, Vozes. TELLES, Vera. (2015), "Cidade: produção de espaços, formas de controle e conflitos". Revista de Ciências Sociais (UFC), 46:15-42. Disponível em http://www.periodicos.ufc.br/revcienso/ article/view/2423, consultado em 10/07/2020. 
TELLES, Vera. (2019), "Violência como forma de poder". Dossiê: Estado de choque -Le Monde Diplomatique Brasil, São Paulo.

VIANNA, Adriana. (2019), "Políticas da morte e seus fantasmas". Dossiê: Estado de choque - Le Monde Diplomatique, São Paulo.

VIANNA, Adriana. (2018), “As mães, seus mortos, nossas vidas". Cult, 232.

VIANNA, Adriana \& MAGALHÁES, Alexandre. (2019), Habitar a cidade e fazer a vida: questóes sobre a existência em situaçôes limite. In: Bello, Enzo; Keller, Rene José. (Org.). Curso de Direito à Cidade. 2ed. Rio de Janeiro, Lumen Juris, p. 1-15.

TORRES, Ana Carolina. (2018), "Moradores e ONG denunciam truculência em operação na
Maré, na Penha e no Alemão", Jornal Extra, 21 ago. Disponível em https://extra.globo.com/ casos-de-policia/moradores-ong-denunciamtruculencia-em-operacao-na-mare-na-penhano-alemao-22996998.html, consultado em 10/07/2020.

WITZEL, Wilson. (2018), “A polícia vai mirar na cabecinha e... fogo', afirma Wilson Witzel”, Uol Notícias, $1^{\circ}$ nov. Disponível em: https:// noticias.uol.com.br/ultimas-noticias/agenciaestado/2018/11/01/a-policia-vai-mirar-nacabecinha-e-fogo-afirma-wilson-witzel.htm. Consultado em 10/07/2020.

ZALUAR, Alba. (1985), A máquina e a revolta. São Paulo, Brasiliense. 


\section{A GUERRA COMO MODO DE GOVERNO EM FAVELAS DO RIO DE JANEIRO}

\section{Alexandre Magalhães}

Palavras-chave: Favelas, Rio de Janeiro, Guerra, Destruição, Vida.

Minha intenção neste artigo é discutir como a guerra é um recurso político de governo da vida e da morte de determinadas populaçóes na cidade do Rio de Janeiro. Nesse sentido, sugiro pensar as relaçóes entre os diferentes aparatos estatais e os moradores de favelas cariocas a partir da "lógica da destruição", na qual a guerra emerge como o modo mesmo de governar estas populaçóes. As reflexôes aqui apresentadas se sustentarão na análise da intervenção federal nas forças de segurança estaduais implementada em 2018 no Rio de Janeiro. Intentarei demonstrar dois processos interconectados, dando ênfase, nesse texto, ao primeiro deles: por um lado, como as experiências de vida destas populaçóes se constituem a partir de uma constante exposição à morte, a formas de destruição de seus modos de existir na cidade e à produção de dor e sofrimento. Por outro, quais formas essas pessoas criam para contornar ou atravessar a destruiçáo e a devastação, a fim de continuar existindo e reabitar a vida.

\section{WAR AS A GOVERNMENT MODE IN RIO DE JANEIRO'S SLUMS}

\section{Alexandre Magalhães}

Keyword: Slums, Rio de Janeiro, War, Destruction, Life.

My intention in this article is to discuss how war is a political resource for governing the life and death of certain populations in the city of Rio de Janeiro. In this sense, I suggest thinking about the relations between the different state apparatuses and the residents of Rio's favelas based on the "logic of destruction", in which war emerges as the very way of governing these populations. The reflections presented herein will be based on the analysis of the federal intervention performed in 2018 in the state security forces in Rio de Janeiro. I intend to demonstrate two interconnected processes, emphasizing the first in this text: on the one hand, how the life experiences of these populations comprise from constant exposure to death and ways of destroying their ways of life in the city to the creation of pain and suffering. On the other hand, what forms do these people create to circumvent or cross destruction and devastation in order to continue to exist and re-live life.

\section{LA GUERRE COMME TYPE DE GOUVERNANCE DANS LES BIDONVILLES DE RIO DE JANEIRO}

\section{Alexandre Magalhães}

Mots-clés: bidonvilles; Rio de Janeiro; guerre; destruction; vie.

Cet article vise à montrer combien la guerre est une ressource politique utilisée pour gouverner la vie et la mort de certaines populations dans la ville de Rio de Janeiro. Les relations entre les différents appareils étatiques et les habitants de bidonvilles de Rio de Janeiro sont pensées à partir de la " logique de la destruction ", pour laquelle la guerre est perçue comme la manière de gouverner ces populations. Les réflexions présentées dans ce travail se basent sur l'analyse de l'intervention fédérale des forces de sécurité de l'État de Rio de Janeiro, mise en place en 2018. L'objectif est de démontrer le lien entre deux processus, en mettant ici l'accent sur le premier: d'un côté, les expériences de vie de ces populations se constituent à partir d'une exposition constante à la mort, aux formes de destruction de leurs façons d'exister dans la ville et à la production de douleur et de souffrance. D'un autre côté, ces personnes créent des stratégies pour contourner ou traverser la destruction et la dévastation, et ce, afin de continuer à exister et à habiter de nouveau la vie. 